http://dx.doi.org/10.18778/1508-1117.21.08

\author{
Antonio Violante
}

\title{
SREBRENICA: WHERE THE WAR NEVER ENDED
}

\begin{abstract}
In Bosnia and Herzegovina changed both by the 1992-1995 war and the Dayton peace which was imposed from outside and which officialised the nationality-based division of the country, the contrasts that exploded during the conflict are still unsolved. The political forces still base their electoral consent upon nationalistic themes, while the population has lost faith when it comes to a prospective of an economically better future. A good example of this situation is the town of Srebrenica and its surroundings, where Europe's biggest genocide since WW2 took place. There rest thousands of Muslims killed in July 1995 under the eyes of the UN military forces. The cemetery, a tangible symbol of the horrors which happened at the end of the XX century - not so different from the Nazi concentration camps that were left standing for the whole world to see and for the generations to come to keep as a warning - should inspire absolute respect in anyone. But it does not. This area is inhabited mainly by a Serbian population, and is exposed to insults and abuse from people driving by.

Twenty years from the genocide - which is considered as such by Muslims only and not by Serbs - true peace is still far away, and the nationalities - ex enemies but still rivals - think that only their own dead are to be remembered, while those others are only result of media publicity. Yet if all that can happen in the Third millennia Europe, it means that there is still something wrong in the continent.
\end{abstract}

Key words: nationalism, genocide, negationism, United Nations.

\section{Introduction}

This study wants to delineate a picture of the municipality of Srebrenica in Bosnia and Herzegovina around twenty years after the end of the 1992-1995 civil war, and after the horrifying massacres that happened in the area after the armed forces of the Republic of Srpska (RS) conquered it. This manu military occupation of the city and its surroundings happened despite the ONU protection of the Srebrenica enclave and despite the presence of around 400 Dutch ,blue helmets” that were protecting its integrity and that of the 40.000 Muslims refugees in the area. 
It aims to verify not only if the residues of the 1995 have disappeared in 2015, but also and especially if the two resident communities of the town and its surroundings - Serbs and Muslims - now live in reciprocal respect sharing the memory of what happened, or the hatred towards the enemy still lives 20 years after the end of the war.

This was not a research that followed a methodology capable of producing "scientific" data. On the contrary, the main goal was to verify points of view and feelings of those who live there through analysis and interpretation of ample documentation.

\section{Geography and history}

The municipality of Srebrenica is situated on the left bank of the middle course of the river Drina. It is located in the region of Vlasenica, one of the seven that make the Republic of Srpska, entity of the state of Bosnia and Herzegovina. The main inhabited centre that gives the name to the whole municipality is built along the valley of the small river Križevica, flowing into the Drina about $10 \mathrm{~km}$ along the valley, near Bratunac. In Roman age, the river Drina and its course have represented the boundary between the Latin linguistic/cultural area on its left bank, and the Greek one on the right. Following the definitive scission of the Empire that boundary became political too, marking the limits between the Western and the Byzantine empires. Furthermore, after the 1054 schism, Drina's course separated the western area of the Roman Catholicism from the eastern Orthodox one. We can deduce that the river represented a "strong" frontier even before the early Medieval Slavic migrations in the region and before the advancing of the Islam following the Ottoman Empire's conquering of the Balkans.

In the XX century, the Bosnian part of Podrinje has seen ferocious battles for the territory between Serbs and Muslims, both during the 1941-1945 war and the 1992-1995 conflict. In both wars, the Serbian component tried to transform the region into a territory inhabited exclusively by Serbs by trying to expel Muslims completely. According to the Serbian point of view, the theory that saw the entire region of Podrinje as a part of Serbia has historical motivations. In fact, there is a paragraph written by the Byzantine writer Giovanni Cinnamo,

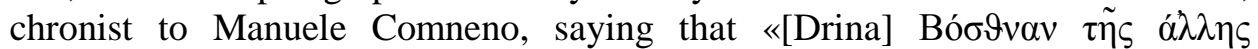

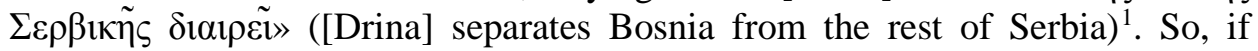

${ }^{1}$ III, 7, 7-10. It is significant that this text by Giovanni Cinnamo has been used in a Serbian publication regarding Drina, and published in two Serbian cities, Belgrade and Srpsko Sarajevo (Jovanović, Hamović 2005, p. 455), in order to give credit to the theory that saw Bosnia belonging to Serbia already in the Medieval Ages. This is a case of use of historical past in order to give more authority to a present claim. 
Bosnia was considered as a part of Serbia, it is obvious and only right to assume the same for western Podrinje, inside and including Bosnia.

So, the attack to the Muslim enclaves of Srebrenica, Žepa and Goražde during the 1992-1995 war was only an attempt to re-conquer the territory that use to belong to the Serbian people ever since the Medieval age, and was stolen to its legitimate inhabitants following the Ottoman Islamic invasion. The 1991 census counted 37.211 inhabitants in the municipality of Srebrenica, out of which 27.118 (72,88\%) were Muslims, 9.381 (25,21\%) Serbs and the rest of the residents belonged to minority national groups, or were "non declared". The data regarding just the urban core had similar percentage numbers: 3.683 Muslims (64\%) and 1.649 Serbs (29\%) over a total of 7.754 inhabitants $^{2}$. The demographical data obtained with the 2013 autumn census in Bosnia are still being elaborated and are not available, mostly because of the contrasts between the Federation of Bosnia and Herzegovina (FBiH) and the Republic of Srpska regarding interpretation of data (Jukić 2015).

However, one thing is certain: the fact that the density of the habitants is quite reduced compared to the situation before the war, and according to preliminary results, the entire municipality of Srebrenica (not just its urban centre, whose data is not available as of October 2015) counts 15.242 inhabitants $^{3}$.

\section{Srebrenica today}

There were no censuses in Bosnia for 22 years because the obvious demographic and habitants' variations compared to the 1991 data were to be hidden officially. In fact, the Dayton peace agreement signed on November $21^{\text {st }} 1995$ took in account results obtained on the battlefield: on one hand, it recognized to the Croatian-Muslim federation the $51 \%$ of the Bosnian territory and to the Republic of Srpska the remaining $49 \%$. However, on the other hand, by legitimising the right to return for all the refugees they established the - albeit theoretical principle of the habitants' situation being the same as the one "pictured" during the 1991 census. So, because there was no will to alter the delicate balance reached through Dayton agreement, the electorate lists remained the same as in 1991 (excluding the obvious registry data updates). In fact, in single municipalities, those who were resident elsewhere because of war consequences kept their right to vote. A good example of the consequences of such situation was the composition of the municipal council of Srebrenica, where a Muslim mayor was elected.

\footnotetext{
${ }^{2}$ Dates from Bosnian Congress, USA, August 1997.

${ }^{3}$ Agency for Statistics of Bosnia and Herzegovina. Online at http://www.bhas.ba/ obavjestenja/Preliminarni_rezultati_bos.pdf.
} 
In fact until 2012, despite belonging to Republic of Srpska and being inhabited by Serbs in sensibly bigger percentage (according to the estimates) than in 1991, Srebrenica had a Muslim mayor. During the administrative elections in October 2012, the new rules did not give right of vote to those resident in Srebrenica before 1991 that consequently moved elsewhere. This made the results even more uncertain than before. In fact, until the last moment it appeared that the nationalists' candidate from RS Vesna Kočević would prevail over Ćamil Duraković, who was the candidate of a mixed civic, Bošnjak-nationalist coalition. Such a result would have been a heavy blow not only to the city, but to entire Bosnia and Herzegovina: in the city that is a symbol of atrocities and ethnic cleansing in the country and where the International Criminal Tribunal for the former Yugoslavia (ICTY) recognized the existence of genocide after those in Europe during WW2, there would be the election of a candidate whose party's leadership and members not only approved of said genocide (also gaining advantage from it) but took active part in it, as executors or instigators.

However, Kočević proposed herself as a candidate of "reconciliation" between Serbs and Muslims, having declared that she was no "revisionist" (negationist) regarding what happened, adding that she was aware that in Srebrenica numerous crimes were committed; but then she did add "on both sides". There are two considerations to be made in regard to this: 1) in her proclamation of "non negationism" she never pronounced the word "genocide"; 2) the 8.732 white gravestones in the Potočari memorial site were the consequences of a "crime", one of many perpetrated by both parts. This is an experienced technique: when a crime is to be blamed on an entire society and responsibility should be generally shared, what is really happening is that the role of those truly responsible is being minimized. Therefore, all were guilty = nobody was guilty.

\section{The Serbian point of view}

It is also obvious that a true reconciliation is yet distant, especially in Srebrenica: this can be seen in the words of the Serbian president Tomislav Nikolić pronounced on October $9^{\text {th }} 2012$ during a state visit to Rome: "no Serb has ever recognized the genocide, not even myself" (Sasso 2012). In fact, not much different from what the president of Republic of Srpska Dragan Čavić said after Banja Luka's streets were covered with posters negating that the RS Army ever committed crimes in Srebrenica: "there is no basis for speaking of genocide" when it comes to Srebrenica (Picard, Zinbo 2012, p. 142). But if Serbian politicians - who have also international responsabilities - admit to atrocious crimes having been committed despite negating that Srebrenica saw genocide, no such thing emerged in the RS's public opinion. Between the Bosnia 
and Herzegovina's Serbs and the "negationists" and "conspiracy" currents of international public opinions, there are many believing that the Serbian population was the designated victim of an attempted genocide by the international Islamic jihad forces. Such an attempt supposedly happened during the 19921995 war, with the support of the world's "great powers" including international organisations such as UN and NATO; furthermore, all of that with the only purpose to negate the Serbian population their right to live in historically inherited lands. Such opinions can easily be confirmed by publicity distributed abroad too and translated in various languages. For example:

1. Thanks to the media resonance of Srebrenica, "the American imperialism and their vassals - appendixes have accomplished the perversion of "transforming Serbs of a genocide perpetrated by the Catholic Church and the Nazis, into a fascist population of felons. Clinton, the social-democrat Schröder and the green Fisher are the political executors of Hitler's testament” (Priskil 2012, p. 9).

2. Already in 1991 Bosnian Muslims were getting armed, preparing for war (Dorin, Jovanović 2012, p. 28).

3. Serbs attacked Srebrenica because they were exasperated by being victims of massacres, expulsions, torture, violence and humiliations during the ex Yugoslavia wars (Corwin 2007, p.19).

4. In Serbian press the Bosnian component (them) is presented as a religious group (Muslims) without political legitimacy, while Serbs and Serbia (us) are depicted as pacific and forced to react to Muslim attacks and provocations, along with being victims of an undeserved international disapproval; furthermore, in the aftermath of Srebrenica's fall the Serbian press justified the events as the reaction to "Muslim terrorists attacks", describing the context for the conflict against the Bosnian Army was compared to a war against terrorism ${ }^{4}$.

5. The real number of Muslims killed in Srebrenica is supposedly not the one reported by the international community, but more close to 700 (Corwin 2007, p. 18).

6. Srebrenica was not a disarmed protected area, because the Muslims used it as a base in order to attack the nearby Serbian villages (Herman 2007, pp. 36-37 and MacKenzie 2007, p. 68).

7. After conquering Srebrenica, the Serbian army's behaviour towards Muslim civilians was irreproachable, while previously the Muslim army hunted, tortured and killed the Serbian population with no regard whatsoever for sex or age (Dorin, Jovanović 2012, p. 30).

8. What happened in Srebrenica was not a genocide, but only ethnic cleansing: a true premeditated genocide did happen, but in 1995 in Krajina, where the Croatian army eliminated all the Serbs they found in tens of villages of the region (Herman 2007, p. 44 and Branco 2007, p. 74).

\footnotetext{
${ }^{4}$ N. Gaon (2012, pg. 46 and 50). This work has analysed the different representations of the fall of Srebrenica in Sarajevo and Belgrade press.
} 
9. The Muslim propaganda made USA liberals believe that the cruel Serbs had destroyed the multi-ethnic Bosnian oasis governed by Osama Bin Laden and his friend and ally Alija Izetbegović (Herman 2007, p. 51).

10. Srebrenica had fallen without fighting back despite the strong Muslim military presence inside, because armed resistance would have ruined the victim image for the Muslims that they carefully built and protected no matter the price (Branco 2007, p. 71).

11. If the Serbs truly did have in mind a genocide project, they would not have left possibility of exit from the Srebrenica enclave (Branco 2007, p. 74).

12. Sarajevo's government was aware of the impossibility to defend the enclaves, and instead chose to exploit the fall of Srebrenica in the media, making it appear as a genocide in the eyes of the international public opinion, while it was merely ethnic cleansing in reality (Branco 2007, p. 74).

13. The general Ratko Mladic had offered the possibility of surrender to the Muslim military present in Srebrenica, along with a guarantee of the status of war prisoners. Yet the Muslim command refused such proposal, preferring sending armed forces to Tuzla through the Republic of Srpska's territory; it was during such operation that most Muslim soldiers were killed (Bulajić 2007, p. 77).

In the author's opinion, in order to understand the perception and the interpretation of the facts regarding Srebrenica's fall in Serbian minds, it is particularly useful to consider the Report of the Government of the RS, published in a limited number of copies in September 20025. It had been commissioned by the Human Rights Chamber (HRC) for Bosnia and Herzegovina $^{6}$, whose institutional duty was not to examine the individual criminal responsabilities $^{7}$, but to verify the existence of a possible involvement of the RS Government in the Srebrenica genocide. According to the Serbian nationalists' point of view, the High Representative (HR) Paddy Ashdown prohibited the distribution of such Report, ordering another to be produced, defined as "suitable for official propaganda, [and redacted] by a new commission at his own orders" (Kerečki 2007, p. 89). In the preamble of the first report - that however remains an official document produced by an almost-sovereign political body such as the RS - it is specified how "the events in and around Srebrenica cannot be seen as separated by nationality in relation to crimes committed by members of so-called Army of Bosnia and Herzegovina comprised mostly by Moslem's Jihad warriors and to possible crimes of members of the Army of Republic of Srpska". Therefore, full legitimacy is given to one of the two

\footnotetext{
${ }^{5}$ Online at: http://www.domovina.net/srebrenica/page_006.php.

${ }^{6}$ In Bosnian: Dom za Ljudska prava za Bosnu i Hercegovinu, operating between March 1996 and December 31 $1^{\text {st }}$ 2003, was a judicial body della BiH within the annex 6 of the Dayton Peace Agreement.

${ }^{7}$ Of the International Criminal Tribunal for the former Yugoslavia's competence.
} 
opposed sides, while the other one is delegitimized and compared to Islamic Jihadists: consequently, the announced objectivity of the report that according to the preliminary announcements was suppose to be based upon facts without considering the nationalities of those responsible for them, is immediately denied by the hereinafter of the report itself, attributing asymmetrical roles to the parts. There is mention of a supposed massacre of Muslims in Srebrenica in 1995, compared to the certainty (in the eyes of the Serbs) that during the entire 1992-1995 period most of the victims were of Serbian nationality. The 2002 report continues, specifying that during the entire period of war there were no paramilitary Serbian units in Srebrenica because they were - supposedly - fully incorporated in the regular RS army ever since 1992. However, in June 1995 during the Slobodan Milošević trial, the ICTY made public a video where men in mimetic apparel belonging to the "Scorpions" militia (composed of agents at the orders of the Belgrade Ministry of Internal Affairs) gunned down six Srebrenica Muslims, out of which two were minors, with an Orthodox priest blessing the assassins ${ }^{8}$. Killings of Muslims done by Serbs outside of official battles were indeed admitted, but they were considered sporadic personal vengeances made by the families of victims massacred in 1992-1993; in fact, the presence of Ratko Mladić - Chief of Staff of the Army of the RS - in Potočari would have made systematic executions and killings impossible, considering his famous intolerance towards unlawful behaviour. As for the mass graves, they were made for hygienic reasons because of many deaths in combat. The report also laments how there is concrete possibility of becoming extinct for the Bosnian Serbs, because of the Islamic fundamentalists' project to overwhelm Serbs and Croats demographically in near future, considering the Muslims' propensity to multiply much more rapidly than other nationalities; the final result would be a Bosnia and Herzegovina under Muslim domination obtained merely through their demographic superiority.

Finally, not only the possibility of a Serbian responsibility in the 1992-1995 civil war is rejected, but the blame is entirely placed on the Muslims; they

\footnotetext{
${ }^{8}$ The protagonists of the video, therefore, cannot even be mistaken for a paramilitary group out of control of the legitimate authorities. Nataša Kandić (also called Belgrade's Simon Wiesenthal) came into possession of this video, given to her by a member of the group that did the execution and who regretted the crime; afterwards she forwarded it to the ICTY. However, despite proof such as this one that could unequivocally pin the authors of the massacre to their own responsibilities, it was evident that still in 2005 Serbia did not show any will to deal with the past. An independent survey done by "Strategic Marketing" revealed that over 50\% of Serbs did not believe that Yugoslav forces had committed such crimes during the ' 90 s war; furthermore, $2 / 3$ of those interviewed considered Ratko Mladić and Radovan Karadzić heroes of their country (in regard to this: "Srebrenica: un video smaschera i massacratori dei musulmani", www.laRepubblica.it, 2 giugno 2005; Battistini 2005).
} 
attempted to create an Islamic $\mathrm{BiH}$, with the Serbs and the Croats [sic] of Bosnia that fought to contrast such attempt upon realising Izetbegović's intentions.

A new Commission wanted by Paddy Ashdown whose exact title was "Commission for Investigation of the Events in and around Srebrenica between 10 and 19 July 1995", ended its job in October 2004. The report was accepted by the RS government, that published its considerations about it on October $28^{\text {th }}$ 2004 signed by the Prime Minister Dragan Mikerević ${ }^{9}$, saying: "Report doubtlessly demonstrates that, at the area of Srebrenica in July 1995, were committed crimes of huge extent, by means of rude violation of the international humanitarian law". However, a further passage specifies how "guilt cannot be general or collective. Perpetrators always have name and surname, and they won't be judged because they belong to or represents one nation, but because of what they did". In other words, the RS Government negated any responsibility whatsoever of the 1995 Serbian institutions, which at the time were lead by Karadžić as the political leader and Mladić as military commander. Contrarily to what the 2002 Report said, blaming entirely the Muslims, opens to the possibility of crimes committed by the Serbs, but only individual ones, therefore auto-absolving the RS institutions in the eyes of the HRC, since the 2004 authorities were the same as in 1995 (and consequently remain the same in 2015 too). This declaration also says that the "Goverment of the Republic of Srpska believes that work and results of work of the Commission would contribute to creating of climate of confidence in Bosnia and Herzegovina and in wider region". This is an auspicated "climate of confidence" that however 20 years after the end of the war is still not a reality in $\mathrm{BiH}$ or in the larger region of the western Balkans.

\section{Genocide, nationalism and the Western role}

Today from Bratunac to Srebrenica (included) along the road connecting the two towns and with the abandoned factory hangars in Potočari as the epicenter, even in a sunny summer day there is a ghostly death atmosphere, which is amplified by the white structures and tombstones of the memorial built to hold the rests of the July 1995 victims. Walls and tombs are not being damaged or outraged by offensive writings, also because there is a permanent police post there. However, there are those who drive by and should insults to the victims in the loudest way possible ${ }^{10}$. The place now has an extremely strong symbolic value for the Muslims, given not only by religious motivations; still, it has no meaning for the

9 These can be consulted online too at: http://www.domovina.net/srebrenica/page_ 006.php.

${ }^{10}$ The author saw personally this situation during visits to Srebrenica and the Potočari Memorial in 2012 and 2014. 
Serbs. This is a tangible sign of the fact that the only thing that ended with the Dayton peace is the war that was fought physically between 1992 and 1995. But there was no real pacification, if there are still those who insult the dead (and the alive) on both sides. The WW2 would not have truly ended if the neonazi were to travel to Auschwitz and Birkenau in order to outrage the memory of the victims in those places. The Polish government and the whole civil world would never allow that: if such event ever occurred, it would immediately make headlines through the entire world.

But the term "respect" does not live in Srebrenica yet. There are heavy responsibilities for such a devastating result weighing not only on the UN, but also over the European forces that allowed the massacre to happen. The heaviest burden falls upon the absolutely inconclusive UN chain of command, and the United Nations Protection Force (UNPROFOR) Dutch battalion situated in Srebrenica and meant to protect the enclave. From July $11^{\text {th }}$ on, despite seeing with their eyes what was happening, the battalion turned away and faked ignorance: they even collaborated with the Serbian attacking forces, culminating in a toast to celebrate the end of operations, and according to what has been proved during the trial, they cancelled some of the names on the lists of those collaborating with the UN: without this, the owners of those names would have been saved, while the cancelling meant automatically execution by the Serbs.

The author is convinced that it would have been better if the UN and NATO did not take part in the conflict. By coming between the parts, these organisations not only delayed but also did not avoid the course of events, and have ended up extending the duration of destroying, death and social decline. Therefore, it would have been better to allow the conflict to unfold "in a normal way", so the winner would have been right and those defeated would have been wrong, as it usually happens during wars but much more quickly than it really occurred. All of this would have happened only if the $\mathrm{BiH}$ was allowed to defend itself as an internationally recognized sovereign state. In fact, the weapons embargo against Bosnia was criminal, despite the right to self-defence recognized by the very UN. The author does realise that such opinions are in direct contrast with the one attributing to the Serbs most of the responsibilities for the civil massacres which happened during the 1992-1995 war; those sustaining such theory would have wished for a Western intervention that would have stopped the conflict immediately ${ }^{11}$. However, and first of all, since the West is not a unique entity, it would be necessary to define what does such term imply: the NATO, only the USA in the role of "the policeman of the world" because it is the only remaining superpower, the EU in the beginning of the " 90 s when it was freshly constituted and had 15 members? The United Nations are

${ }^{11}$ An example of critique by A. Lallo (2011, p. 20). According to this author, the West intervened only over symptoms of the conflict without ever touching the causes, and therefore failing to avoid thousands of deaths, rapes, destroyed families, refugees. 
not to be considered, because it is an organisation made of almost every state in the world (and therefore not only those in the West) and its role is to prevent war between states, but without power of intervention in internal conflicts such as the Bosnian one. Furthermore, it is not comprehensible why this "West" should have defended multi-national cohabitation, preservation of the person and human dignity, legitimized therefore to do a role of peacekeeper in the conflict as the sole depositary of moral values that aren't intrinsic in any other state in the world. Such values should have induced some "western" countries to intervene in $\mathrm{BiH}$ on the bases of political motivations, yet induced by pursuit of a humanitarian altruism and not by personal interests. However, this type of West did not exist in the '90s nor it exists today, and the only thing it has accomplished was either to exacerbate or prolong already existing conflicts, or to start - in the name of democracy - "humanitarian wars" that could not be stopped afterwards, even if they did wear the name "peace missions" 12 . The consequences of the insanity produced not only by the parts involved by also by the international forces are under the eyes of the world. The Country, that could have Srebrenica as its symbol, has been pacified forcibly by the USA, even though 20 years afterwards there is no real peace based on the will to resuscitate the country with the contributions of all of its components. So, according the political parties and in the eyes of the public, the blame for the lack of the prospective for the future of the country is always to be placed on the opposite national group. The enemy started the war, and perpetrated many crimes that are still unrecognized by the perpetrator himself: this way, in retaliation, no nationality admits any of its crimes even when they are obvious. The genocide never existed and those who say it did are traitors and stand on the other side.

But in Srebrenica's case things did not stop there: if genocide did really exist as the Hague International Tribunal ruled in February 2007, according to the pro-Serbian publishing, it was the Muslims who did it to the Serbs. In fact, there is supposed proof that the Muslim army hunted, tortured and killed Serbs in Srebrenica and around it, without caring about age or sex of those people. On the contrary, the Serbian army treated the Muslim civilians after the fall of Srebrenica. Not only: the evacuation of the Muslims from the city in July 1995 happened upon request of the very Muslim civilians who were afraid of a Serbian vengeance from the surrounding villages, who lost their relatives during the massacres perpetrated by the Muslim army (Kerečki 2007 and Dorin, Jovanović 2012, passim).

Considering that the Srebrenica massacre against the Muslim inhabitants and the enclave refugees who were under the UN protection is one of the most documented in history, such words need no further comment. However, by using

${ }^{12}$ Among numerous references in this matter, C. Jean (2012) and N. Chomsky, A. Vltchek (2013) are particularly significant. 
a definition by Andrea Rossini, 2014, we can notice how "the elaboration of the past happens through admission of one's crimes, not those perpetrated by others".

The negationism of the Srebrenica facts - and more generally of Muslim Bošnjaks - is particularly common in Italian publishing too ${ }^{13}$, and it includes opinion currents of every political orientation, from extreme right wing to the extreme left wing, and even pro-Islamic/anti-Americans (Franzinetti 2010, p. 245-246). This happens despite extremely precise lists of the victims which were obtained by confronting the 1991 Yugoslavia census data with the one from the 1997 and 1998 elections, opportunely cleaned out from doubles and possible homonymy in a collation of heterogeneous data: for every missing person there were accurate investigations in order to establish the reasons of the disappearance, obtaining results with a level of accuracy that was well above the one regarding numbers of victims in other massacres, announced by the media and that were not and will not be, not even in the future, controlled by anyone (Franzinetti 2010, p. 244). According to the bitter comment of Guido Franzinetti, the only positive aspect of this matter is "the fact that Bosnia's massacres are and will remain the best documented of the second half of the XX century" (Franzinetti 2010, p. 250).

Stances such as those exposed are not limited to restricted groups in Serbia and Bosnia, but are largely shared between public opinions; they are continuously spread by the local media and the politicians that aims to put the blame of everything that is wrong upon the opposite national groups, in order to maintain their followers among their electors and easen their re-election. The war between nationalities continues in other forms this way, in a country that is among the poorest in Europe, refused by the EU despite its position in the heart of the continent, and above all without a shared project of how to exit its crisis and how to escape from the ghosts of an unsolved conflict despite all the time that has passed.

\section{True peace is still far away}

The author is convinced that the true peace cannot arrive following merely the convictions in tribunals for those responsible of crimes. On the contrary, this only augments the level of hatred and reciprocal accusations, especially because the tribunals normally pursue the others' crimes, not of those belonging to the nationalities under whose jurisdictions they operate. A possible solution could

${ }^{13}$ Exemplary cases in this matter I. Kerečki (2007) and A. Dorin, Z. Jovanović (2012), previously mentioned. The introduction of the latter (p. 7-17) is signed by the Italian legal expert Aldo Bernardini, professor of International Law at the University of Teramo. 
arrive by adopting the system actuated in South Africa at the beginning of the ' 90 s while abandoning apartheid in favour of a democratic system. Nelson Mandela and Frederik de Klerk, leaders of the main black and white parties, chose intelligently to stop a heinous regime of racial segregation and a situation which was bordering on civil war, without juridical persecution of the authors of crimes and violence's: if this could have somehow satisfied the families of the victims in case of a conviction, it would have lengthened instead of breaking the hatred chain one hand, and on the other it would have augmented the risk of vengeance in case of disagreeable sentences. Also on the contrary, cancelling altogether all of the crimes would not only have been unfair, but also counterproductive. The survivors of those crimes and the family members of the victims have the right to see what happened publicly shared and also officially recognized. So in South Africa, following the decision of the two leaders ex enemies, all those guilty of racial crimes were able to gain a judicial pardon including police members - if only they admitted publicly and without holding back the things they have done.

Nothing of a sort happened in Bosnia, and in particular in Srebrenica, despite the fact the HRC judges had in mind a solution such as the one made by the Truth and Reconciliation Commission of South Africa (Picard, Zinbo 2012, p. 136). Despite some convictions, there is a lack of will to truly pursue those responsible and to throw light completely upon war crimes. This way the victims and their tormentors live as neighbours: everybody knows what everybody has done and has suffered, but without any official recognition of what has happened between 1992 and 1995. The torturers are not hiding and have no shame for what they have done. On the contrary, they can walk freely being proud of their actions and being considered as heroes by their national communities. This is happening despite the fact that the ICTY said that the killings happened following programmed actions and were not caused by individual actions of Serbs frustrated by Muslim raids over their houses during previous years; and furthermore, they were not the result of actions of single divisions that escaped the control of their commands. There was will to eliminate a whole population in Srebrenica and its surroundings, inside a conflict where elimination or removal of civilians belonging to "enemy" nationalities were not collateral events of battles between opposing armies, but the goal of the very war. And after that war ended, "negationism is the final phase of genocide" (Nuhefendić 2010, p. 15).

Obviously in such context there is no possibility of any reconciliation. What is more frustrating for the victims is not the lack of punishment, but the lack of public admission of what happened, despite the fact that it is well known by the whole country, and obviously even better known in a relatively small city where everybody knows everybody. The true peace will "burst" not only when rebuilding churches and mosques in Srebrenica and other Bosnian localities is done; furthermore, it will get no closer with initiatives such as that of the municipal assembly in Srebrenica (with a Muslim majority) on March $24^{\text {th }} 2007$. 
They had decided for a request of exit of the municipality from the Republic of Srpska, with a vote that saw the Serbs in the assembly absent. Such an action could not have any practical effect, considering that the Republic of Srpska is a political entity with an internationally recognized territory, and that cannot be modified with unilateral resolutions. On the contrary, peace will get closer when, thanks to a European helping hand, the country will be able to break free from an intolerable economical situation resulting in poverty and unemployment.

However, mere economical and financial assistance is not sufficient to start a virtuous process of growth. Srebrenica, whose name is associated with one of the most inhumane tragedies of the XX century, has largely benefited from domestic and international help. However it is still underdeveloped, and only partially because of the war disaster. The unemployment percentage is high also compared to the national standards; there is also scarce industrial production. What weighs negatively is also the decentralised position of the town, in a remote area of the country. We should add that its potential commerce and political relations that accompany economical activities with its traditional partners and main cities are in another political and administrative entity of Bosnia, the Federation of Bosnia and Herzegovina (FBiH), and Srebrenica is not a part of it. An inevitable consequence: further loss of trade ${ }^{14}$.

But however, there is absolute need of growth of economical activities in order to guarantee an income to the residents and to favour the return of the refugees. However the demographic data and the occupational percentages are adverse: there are few young people that chose to go back and live in the region, and the only possibilities of jobs are in the agriculture, manual labour and low value-added manufacturing, with very little opportunities of professional requalification. Not only among the old, but also among the young there is much regret of the "good old days" from before the war, when under the socialist regime of the time the town benefitted from remarkable industrial installations.

\section{Srebrenica's echo today in the world}

There were some signals of an authentic will of change for a situation that is bordering on unsustainable, arriving from the nearby Tuzla in February 2014. There was a particularly vivacious protest of social and not ethnic nature. Among the anti-nationalistic requests, there is one standing out: the creation of a Bosnian-Herzegovese identity based on citizenship and not on ethno-national

${ }^{14}$ According to the data of the National Employment Agency (ARZ), in December 2013553.481 people were looking for employment, around 2.000 more $(+0,36 \%)$ compared to November of the previous year, when the official unemployment rate was $44,5 \%$. Yet considering the so-called "grey economy", the realistic rate was around 27,5\%, www.ansa.it/nuova_europa/it/notizie/rubriche/. 
division of the inhabitants. Exactly as it used to happen during Yugoslavia, before Bosnia was erased by Dayton. The future that is being requested through protests appears to be more and more European and less based on national differences.

However, national rivalry was reconfirmed during the $20^{\text {th }}$ anniversary of the conquest of Srebrenica by the Serbian army on July $11^{\text {th }} 1995$. On July $8^{\text {th }} 2015$ a Resolution by the United Nations Security Council was put on votes, at the Meeting Commemorating Twentieth Anniversary of Srebrenica Killings. In the intentions of the United Kingdom as the proposing country, this Resolution would have emphasized acceptance of those tragic events as genocide as a prerequisite for national reconciliation in $\mathrm{BiH}$. But it was denied because of the Russian Federation veto because, according to their representative Vitaly Churkin, "to place the blame on one community (...) would be counterproductive, and he urged the sponsors not to put it to a vote. Otherwise, the Russian Federation would be obliged to vote against it. That stance however did not in any way diminish his country's sensitivity to the suffering and pain of victims of the conflict in the Balkans" ${ }^{15}$. This Russian veto that stopped the approval of the Resolution increased the polemics over Srebrenica's events, instead of sedating them. In fact, Munira Subašić, the representative of the association "The mothers of the enclave of Srebrenica and Žepa", defined the New York vote "a shame". According to Ćamil Duraković, Srebrenica's mayor, it was a "defeat of international justice", claiming that "Russians did not give even a second of their thought to the genocide victims, they have merely aligned with Serbia. However Russia was left alone in its decision, and that shows the isolation of some countries that do not recognise the tribunals' decisions.” John Dalhuisen, Amnesty International's Director for Europe and Central Asia, was indignant while releasing the following statement:

The massacre of more than 8,000 Muslim men and boys at Srebrenica in July 1995 revealed the tragic flaws in UN's response to the Bosnian war. Twenty years on the UN Security Council's failure to recognize the murders as genocide is an insult to the memory of the dead. This resolution was much more than just recognizing Srebrenica as genocide. It was also about acknowledging the urgent need to provide justice to the victims and long-term support to survivors, including of sexual violence, and clarifying the fate and whereabouts of the over 8,000 still missing from the war. We welcome that the United Kingdom, leading the negotiations on the draft resolution, and other Security Council members supporting the text stood firm on the need to recognize that the events 20 years ago in Srebrenica constituted genocide. This is a prerequisite for reconciliation,

15 The debate over this Resolution is published online at: http://www.un.org/press/en/ 2015/sc11961.doc.htm. 
and the denial of genocide is betraying the suffering of victims and their families ${ }^{16}$.

On the other hand, the comment of the president of RS Milorad Dodik ${ }^{17}$ was entirely different: after stating as premise that he did not feel "any triumphalism", he thanked Russia for understanding the region's situation, satisfied that through the Russian veto a Security Council resolution that would have incremented BiH's divisions was stopped ${ }^{18}$.

Therefore, international institutions arrived to the $20^{\text {th }}$ anniversary of Srebrenica with only the statement of the European Parliament in Strasbourg from January $15^{\text {th }} 2009$, where it condemns Srebrenica's conquest as "the biggest war crime to take place in Europe since the end of the Second World War". It also placed the responsibility of the criminal acts on the Serbian component, claiming that "multiple violations of the Geneva Conventions were perpetrated by Bosnian Serb troops against Srebrenica's civil population, including deportations of thousands of women, children and elderly people and the rape of a large number of women". The European Parliament expressed also a theory according to which there were not only war crimes in Srebrenica, but there was real and true genocide: "[The Parliament] Calls on the Council and the Commission to commemorate appropriately the anniversary of the Srebrenica-Potočari act of genocide by supporting Parliament's recognition of 11 July ad the day of commemoration of the Srebrenica genocide all over the EU, and to call on all the countries of the western Balkans to do the same" ${ }^{19}$.

\section{Conclusions: not even the genocide anniversary brought peace}

The days preceding the $20^{\text {th }}$ anniversary of Srebrenica saw also an acute debate between the negationists of genocide opposed to those who asked Serbs to explicitly admit to this crime. Both sides claimed that the recognition of their

${ }^{16}$ Online at: https://www.amnesty.org/en/press-releases/2015/07/srebrenica-un-failure-to-pass-resolution-an-insult-to-the-memory-of-the-dead/.

${ }^{17}$ According to him, there was no genocide against Muslims in the region, but genocide against Serbs. In fact, five years prior to the Srebrenica anniversary he had said: "Republika Srpska does not deny that a large scale crime occurred in Srebrenica, but by definition it was not genocide as described by the international court in The Hague. If a genocide happened than it was committed against Serb people of this region where women, children and the elderly were killed en masse" (interview published in The Sidney Morning Herald, July 13, 2010, online at: http://www.smh.com.au//breaking-news-world/srebrenica-massacre-not-genocide-20100713-1083q.html).

${ }^{18}$ Regarding comments to the July $8^{\text {th }} 2015$ Security Council Resolution, A. Rossini (2015a).

19 The 15 January 2009 Resolution is online at: http://www.europarl.europa.eu/sides/ getDoc.do?type=TA\&reference=P6-TA-2009-0028\&language=EN. 
own theories would have been essential to reconciliation. Nils Muižnieks, Council of Europe Commissioner for Human Rights, was strongly critical of the Serbian negationism and he wrote on the Sarajevo newspaper Oslobodjenje on July $7^{\text {th }} 2015$ :

(...) political discourse in Serbia and in Republika Srpska which demeans or blatantly denies the Srebrenica genocide twists the knife in the wound and hinders the process of much needed reconciliation in Bosnia and Herzegovina and the Balkans in general (...) There are in particular three areas in which Bosnia and Herzegovina and Serbia must improve their response to the victims' need. First of all, justice must be pursued. We all know that it takes time to identify, try and punish war criminals (...) Secondly, victims must be supported. Bosnia and Herzegovina must finally provide civilian victims of the Srebrenica genocide with adequate social protection (...) Thirdly, education must be more inclusive. Mono-ethnic schools and the "two-schools-under-one-roof" system which characterize Bosnian education constitute an anachronistic approach which only serves to perpetrate the ethnic divisions which lie at the root of current and past tensions and heavily undermine reconciliation and peace. The education system must promote a genuine knowledge of history in order to facilitate understanding, tolerance and trust between individuals, especially the younger generations. To this end, school books in Serbia and Bosnia and Herzegovina must include an objective testimony of the Srebrenica genocide, portraying it without political or ethnic connotations. Such an impartial teaching of history serves as a powerful antidote to future tensions and represents a fundamental element of any cohesive society ${ }^{20}$.

Also, the demographic crisis of the municipality of Srebrenica reveals quite some unease, accentuated by a very bad economic situation. According to mayor Duraković, interviewed in July 2015 by the journalist Andrea Rossini of "Osservatorio Balcani e Caucaso" (www.balcanicaucaso.org), in the municipality of Srebrenica there are around 7.000 people. When the 2005 mayor Abdurahman Malkić was asked the same question in 2005, he spoke of 10.000 inhabitants. According to Duraković, the process of the refugees' return during the ' $90 \mathrm{~s}^{21}$ was unsuccessful, and the population kept decreasing because of the economic crisis. According to the mayor, it is the availability of work and progress the factor that convinces people to return, because economy helps recreation of relationships and favours reconciliation (Rossini 2015b).

There was the same amount of pessimism - but regarding the possibilities of reconciliation - in the words of Amra Begić, manager of the Potočari Memorial. She said that it was visited averagely by 130.000 people per year coming mainly

${ }^{20}$ Online at: http://www.coe.int/en/web/commissioner/-/addressing-the-needs-of-thevictims-of-the-srebrenica-genocide-must-be-the-priority.

${ }^{21}$ The right to return for the refugees is one of the basic principles that constitute the November $21^{\text {st }} 1995$ Dayton Agreement. 
from the Federation ${ }^{22}$, but also from other parts of the world, and she also claimed that almost every Bosnian Muslim had visited at least once. According to her, after the war, the building of a national identity is based on admitting to having been victims. She would have auspicated a visit from 100.000 people from the RS, but also added that her own country certainly is not Willy Brandt's Germany: in Bosnia and Herzegovina victimism and negationism walk together (Rossini 2015b). In conclusion, her words showed clearly that her country is well far from what happened in Federal Germany, where German society managed to avoid easy victimism for the massacres induced by allies' bombings during WW2 that did not pick their victims, but also avoided auto-absolution from genocide against "inferior races".

Therefore, all the signs that the Srebrenica's anniversary would have gone wrong were there. It failed to start a process of reconciliation among the $\mathrm{BiH}$ communities, and on the contrary, it has highlighted a hatred that has not diminished and that is transmittable to young generations, despite the fact that they had no role in the '90-s events. In fact, the Serbian Prime Minister Aleksandar Vučić, present in Potočari on July $11^{\text {th }}$, was violently contested by a crowd made entirely of Muslims (some were heart shouting "Allah Akbar") to the point of leaving early covered in insults. To this day, the Serbian public opinion does not recognise the impact of the events against Srebrenica's Muslims during the 1992-1995 war. Every community commemorates only its own dead, ignoring what happened to others. In fact, next to Bratunac and few kilometres from Potočari, in a village called Kravica, there is a memorial to Serbian victims killed by Muslims, including 49 people killed on January $7^{\text {th }}$ 1993 (Orthodox Christmas) during a Muslim attack against the village. There is a crucifix with an inscription remembering 3.967 Serbs that died during the 1992-1995 war and 6.469 Serbs who died between 1941-1945, when Bosnian Muslims fought next to the Nazis inside the SS division "Handjar". This monument is a good example of a silent fight that still goes on, because it affirms a "personal" historical truth that is incompatible with the one the others have. And the Serbian victims are remembered in Kravica between posters of Putin and hymns to the RS, produced by those who believe that the Potočari memorial is based on a historical falsehood.

Therefore, when it comes to the last $\mathrm{BiH}$ war every national component Serbian, Bošnjak, Croatian - has built its own "true" story transmitted to the young generations through school material, opposed to the "false" one presented by others; the consequence of this is an augmentation of resentment and further cultural distance between communities that are forced to live next to each other. It is safe to say that what took lifespans of entire generations to happen in the USA after the end of the 1861-1865 civil war, did not happen in $\mathrm{BiH}$. This country still perceives today the tragic events from the past as components

\footnotetext{
${ }^{22}$ The Croat and Muslim entity of $\mathrm{BiH}$, out of two that constitute it.
} 
necessary to the building of an identity based on common belonging to the American nation. Even the descendants of past enemies like to meet and commemorate battles, even if the latter produced an incredible number of deaths: all of that occurs without reciprocal resentment, but with the knowledge that all of them - winners and losers - have built together a great nation. Nothing of a sort happened in $\mathrm{BiH}$, or more generally in the Balkans. The author is convinced that a true peace has not been reached because the Balkans are a land irremediably soaked in hatred ${ }^{23}$, but because of criminal choices made by certain local politicians. Looking for consent among electors of their own nationality and proposing themselves as defenders of that nationality's interests, these politicians have demonised the other nations, pointing them out as "the enemy to defeat", and therefore provoking fratricide wars. Furthermore, they keep doing this even today, and as consequence the $\mathrm{BiH}$ institutions do not function as they do in "normal" countries. However, the EU is considered to have heavy responsibilities too, but not for not being able to stop the 1992-1995 conflict, that was anyway out of its hands. The responsibility lies in the fact that the integration of $\mathrm{BiH}$ (and other western Balkan states) has not been allowed, leaving them isolated as a sort of a "black hole" in the very heart of the continent, without any economic development perspectives and without any short-term EU integration project. In fact, the EU is perceived inside the Balkans as a club for the privileged "inside the Europe that counts", and is an objective to reach that justifies abandoning past divisions, also in the hope for better individual economic conditions.

\section{BIBLIOGRAPHY}

Battistini F., 2005, Così ho trovato il video choc di Srebrenica, „Corriere della Sera”, Archivio, 6 June 2005, http://archiviostorico.corriere.it.

Branco C.M., 2007, Srebrenica, un abuso di fiducia?, [in:] Kerečki I. (ed.), Il dossier nascosto del "genocidio" di Srebrenica, La Città del Sole, Napoli, p. 71-75.

Bulajić M., 2007, Non vi è stato un genocidio a Srebrenica, [in:] Kerečki I. (ed.), Il dossier nascosto del "genocidio" di Srebrenica, La Città del Sole, Napoli, p. 77-80.

Chomsky N., Vltchek A., 2013, On Western Terrorism from Hiroshima to Drone Warfare, Pluto Press, London.

Corwin P., 2007, La mia testimonianza di alto responsabile dell'ONU sul terreno, [in:] Kerečki I. (ed.), Il dossier nascosto del "genocidio" di Srebrenica, La Città del Sole, Napoli, p. 15-26.

Dorin A., Jovanović Z., 2012, Srebrenica, come sono andate veramente le cose, Zambon Editore (Srebrenica, wie es wirklich war, Ahriman Verlag, Freiburg).

${ }^{23}$ This theory is sustained by Robert D. Kaplan (1993) and has successively - rightly so, in author's opinion - destroyed by Maria Todorova (1997). 
Franzinetti G., 2010, Tornare in Bosnia, [in:] Suljagić E., Cartolina dalla fossa. Diario di Srebrenica, Beit, Trieste (Razglednica iz groba, Amsterdam, 2005: De Arbeiderspers), p. 241-250.

Gaon N., 2012, Fall of Srebrenica. Differences in representations of events by Sarajevo and Belgrade print media, LAP Lambert Academic Publishing, Leipzig.

Herman E., 2007, L'analisi degli avvenimenti, [in:] Kerečki I. (ed.), Il dossier nascosto del "genocidio" di Srebrenica, La Città del Sole, Napoli, p. 27-52.

Jean C., 2012, Guerre umanitarie: la militarizzazione dei diritti umani, Dalai Editore, Milano.

Jovanović N., Hamović D., 2005, Drina, Zavod za udzbenike i nastavna sredstva, Beograd-Srpsko Sarajevo.

Jukić E.M., 2015, Disputes Delay Publication of Bosnia Census, Balkan Insight, 9 June 2015, ehttp://www.balkaninsight.com/en/article/political-disputes-delay-publication-of-bosnia-s-census-results).

Kaplan R.D, 1993, Balkan Ghosts: A Journey Through History, St. Martin’s Press, New York.

Kerečki I. (ed.), 2007, Il dossier nascosto del “genocidio” di Srebrenica, La Città del Sole, Napoli.

Lallo A., 2011, Il sentiero dei tulipani. Psiconazionalismo in Bosnia Herzegovina, Infinito edizioni, Roma.

MacKenzie L., 2007, La vera storia di Srebrenica del Generale Lewis MacKenzie, [in:] Kerečki I. (ed.), Il dossier nascosto del "genocidio" di Srebrenica, La Città del Sole, Napoli, p. 67-69.

Nuhefendić A., 2010, Prefazione, [in:] Suljagić E., Cartolina dalla fossa. Diario di Srebrenica, Beit, Trieste (Razglednica iz groba, Amsterdam, 2005: De Arbeiderspers), p. 11-15.

Picard M., Zinbo A., 2012, The Long Road to Admission: The Report of the Government of the Republika Srpska, [in:] Delpla I., Bougarel X., Fournel J.-L. (eds.), Investigating Srebrenica. Institutions, Facts, Responsibilities, Berghahn Books, New York-Oxford, p. 131-147.

Priskil P., 2012, Presentazione, [in:] Dorin A., Jovanović Z. (eds.), Srebrenica, come sono andate veramente le cose, Zambon Editore (Srebrenica, wie es wirklich war, Ahriman Verlag, Freiburg), p. 19-22.

Rossini A., 2014, Il genocidio del vicino, www.balcanicaucaso.org (online on 18.04. 2014).

Rossini A., 2015a, Srebrenica: il no della Russia, www.balcanicaucaso.org (online on 9.07.2015).

Rossini A., 2015b, Ritorno a Srebrenica, www.balcanicaucaso.org (online on 8.07.2015).

Sasso A., 2012, Bosnia: Elezioni amministrative, il trionfo nazionalista e l'incerto destino di Srebrenica, „East Journal. Società politica e cultura dell’Europa orientale”, www.eastjournal.net/bosnia-elezioni-amministrative.

Todorova M., 1997, Imagining the Balkans, Oxford University Press, New York. 


\section{SREBRENICA: MIASTO, GDZIE WOJNA NIE MA KOŃCA}

Zarys treści: W Bośni i Hercegowinie, zmienionych zarówno przez wojnę 1992-1995, jak i narzucony z zewnątrz układ z Dayton, który sformalizował podział kraju oparty o przynależność narodowościową, kontrasty i problemy, które wybuchły podczas konfliktu są w dalszym ciągu nierozwiązane. Siły polityczne nadal opierają swoją władzę na kwestiach nacjonalistycznych, podczas gdy ludność straciła już wiarę w możliwość poprawy sytuacji gospodarczej. Dobrym przykładem omówionej sytuacji jest miasto Srebrenica i jego otoczenie, gdzie miało miejsce największe po II wojnie światowej ludobójstwo w Europie. Spoczywają tam tysiące muzułmanów zabitych w lipcu 1995 roku pod okiem sił zbrojnych ONZ. Cmentarz, namacalny symbol tragicznych wydarzeń, jakie miały tu miejsce pod koniec XX wieku - nie tak różny od nazistowskich obozów koncentracyjnych, zachowanych jako miejsca pamięci oraz przestroga dla przyszłych pokoleń - winien wyzwalać w ludziach szacunek. Niestety tak się nie dzieje. Obszar ten zamieszkały jest $\mathrm{w}$ większości przez Serbów i stale narażony na obelgi i nadużycia ze strony przechodniów. Dwadzieścia lat po ludobójstwie - które jest uznawane jedynie przez muzułmanów, nie zaś przez Serbów - prawdziwy pokój wydaje się nadal sprawą odległą, zaś grupy narodowościowe - byli wrogowie, ale ciągle rywale uważają, że tylko ich zmarłym należy się pamięć i szacunek, uznając pozostałe ofiary za efekt rozgłosu medialnego. Jeśli trzecie tysiąclecie Europy naznaczają tak trudne do rozwiązania konflikty, warto podjąć dyskusję nad sytuacją i przyszłością tego kontynentu.

Słowa kluczowe: nacjonalizm, ludobójstwo, negacjonizm, ONZ.

Prof. dr Antonio Violante

University of Milan, Italy 